\title{
The Relationship among Product Risk, Perceived Satisfaction and Purchase Intentions for Online Shopping
}

\author{
Van Dat TRAN $^{1}$
}

Received: March 29, 2020 Revised: April 18, 2020 Accepted: May 07, 2020

\begin{abstract}
This research investigates the relationship among product risk, financial risk, security risk, privacy risk, perceived satisfaction, and purchase intention. Validated measurements were identified from a literature review. The measurement model and the conceptual model depicting hypothesized relationships were evaluated based on responses from 306 customers using confirmatory factor analysis and structural equation modeling. The results showed that product risk, financial risk, security risk, and privacy risk impacted on perceived satisfaction. Besides, product risk, privacy risk, and perceived satisfaction influenced purchase intentions. Thus, this study focused on the influences of product risk, financial risk, security risk, and privacy risk on their cognitive attitudes toward websites. That means the more consumer perceive security, the more they avoid shopping online. The study is important to show how perceived risk affects online shopping behaviors, and it invites marketers to make necessary adjustments to prevent perceived risks to increase and online shopping to decrease. The findings of this study suggest the creation of a framework on the effect of perceived risk types on online shopping. Managers need to take perceived risks into account when designing their electronic marketing channels. In addition, shopping websites should strengthen their transaction security by appropriately using various available resources and new information technologies.
\end{abstract}

Keywords : Product Risk, Financial Risk, Security Risk, Privacy Risk, Purchase Intentions

JEL Classification Code: M30, M31, M37

\section{Introduction}

The area of e-commerce in developed and developing countries is now growing rapidly. Therefore, Internet users' digital flow experiences have gained increased attention with the rapid development of the Internet in recent year (Skadberg \& Kimmel, 2004). Online shopping is significantly growing, and there is not only a positive outlook for the future of online shopping, but also scientific indicators that forecast a great expansion for Internet purchasing. Despite the positive sides of online shopping, there are negative attitudes toward buying online because of risk perceptions.

${ }^{1}$ First Author and Corresponding Author. Lecturer, Faculty of Business Administration, Banking University, Vietnam [Postal Address: No.36, Ton That Dam Street, Nguyen Thai Binh Ward, District 1, Ho Chi Minh City, 710000, Vietnam] Email: dattv@buh.edu.vn

(c) Copyright: The Author(s)

This is an Open Access article distributed under the terms of the Creative Commons Attribution Non-Commercial License (http://Creativecommons.org/licenses/by-nc/4.0/) which permits unrestricted noncommercial use, distribution, and reproduction in any medium, provided the original work is properly cited.
According to Miyazaki and Fernandez (2001), over the past decade, the Internet has grown significantly, especially in terms of its use as a medium for interaction, entertainment, and trade on the market. Moreover, the Internet is commonly used in economic activities with growing reliance by people. For Chang et al., 2016, Internet shopping is made possible through conventional ways of shopping. In the age of technology, shopping on websites and online exchanges for the majority of people are no longer a strange thing.

Shopping in an online store is like shopping through a paper catalog because both involve the delivery of purchases by mail, and in both cases customers are unable to touch or smell the items (Spiller \& Lohse, 1997). Consumers' actions are mainly based on the presence of cyberspace, such as images, image quality data and consumer video clips, not the tactile experience (Kolesar \& Glbraith, 2000). The qualities of data introduction, routing, and request satisfaction in an intuitive shopping medium are viewed as a progressively significant factor in building electronic business trust than in the customary retailing (Reynolds, 2000). Giao (2020) identified four factors that influence positively customer satisfaction regarding the quality of online services in Tiki. 
vn E-commerce platform in the order of descending strength: trust, customer service, web design and safety.

Along with the convenience of exchanging and trading there are potential risks. Nevertheless, the growing body of literature focused on the study of Internet marketing trends and digital consumer behavior (McGaughey \& Mason, 1998; Novak et al., 2000) has largely ignored perceptions of risk to online purchasing. Despite their consequences for e-commerce, the perceived risks associated with online retailing have received limited attention (Miyazaki \& Fernandez, 2001). While perceived risk theories have been applied to different contexts of consumer behavior (Mitchell, 1999), recent attention has centered on using perceived risk to describe consumer reluctance to use the Internet for a variety of buying tasks (Pires, Stanton, \& Eckford, 2004). Some early research indicates that perceptions of risk may play a minor role in the adoption of online shopping as a primary barrier to the future growth of online trade. Moreover, consumer's concerns regarding website security and privacy protection influenced their cognitive attitudes towards online shopping (Chen \& Barnes, 2007). Other previous research pointed out that the extrinsic factors preventing consumers from shopping online primarily involved transaction security and privacy concerns (Salo \& Karjaluoto, 2007). Mitchell (1999) points out that, when making purchasing decisions, customers are more likely to consider perceptions of risk than maximizing perceived benefits.

This study analyzes the influence of four types of risks, namely, financial risk, product risk, security risk, and privacy risk on consumers' satisfaction and as well as the impact of satisfaction on usage intentions. It also enables us to understand the relevance of usability on strategic indicators of the success of companies by analyzing the impact of perceived usability on consumer satisfaction levels and the intention to use a website. Thus, this research adds to the literature by evaluating how hazard reduces the perceived usability impact on consumer satisfaction and the willingness to use a website. The study is organized as follows.s The working theories will be formalized in the following section. Next, validation procedures for data collection and analysis are explained, accompanied by analytical results. Finally, The author discusses the study's key conclusions, organizational consequences, and shortcomings, as well as some future research possibilities.

\section{Literature Review}

\subsection{Product Risk}

Chang et al. (2016) showed that the perceived satisfaction and purchasing intent are significantly affected by mental attitudes. The results of this study showed that protection had the most significant effect on cognitive trust and confidentiality on perceived risk. Online shopping had higher confusion and risk compared to traditional store shopping due to the influence of cognitive attitudes on online shopping. Therefore, the cognitive attitudes of consumers on the website were even more important. Users might have beliefs about the website's hedonic value, utilitarian value, protection, and privacy. These appraisal values (i.e. cognitive attitudes) transformed into perceived satisfaction of users and purchase intentions. Regarding theoretical contributions, previous research focused on consumer motivation for online shopping from the point of view of consumer value and website function (Childers et al. 2001; Lee \& Overby, 2004; Wolfinbarger \& Gilly, 2001). In addition, Tham et al. (2019) indicated that product risk, convenience risk, and return policy risk have a significant and positive impact on online shopping behavior. Financial risk is found to have insignificant and negative effects on consumer behavior.

Despite the advantages of online trade over traditional trade and optimistic predictions of future growth of online shopping, negative aspects associated with this method of shopping are also becoming critical(Ko et al. 2004). Montoya- Weiss et al. (2003) suggested that the perceived risk depends on the general Internet experience of the buyer as well as on the website data. The risk was defined as a decision feature that represents the variance infeasible results (Gefen et al., 2002). Some researchers have found that the perceived risk in e-commerce has a negative effect on Internet shopping behavior, attitude to consumer behavior, and willingness to implement e-commerce (Zhang et al., 2012). Product risk is the belief that a purchased product can fail to function as originally expected (Kim et al., 2008). Like any non- store shopping, the Internet makes it difficult to inspect physical goods; customers will rely on somewhat minimal information and pictures on the computer screen (Jarvenpaa \& Tractinsky, 1999). Moreover, Rosen and Howard (2000) recommend what they call the e-potential for various products to be sold on the Internet. Engel and Blackwell (1970) found that the need of an opportunity to look at the items prior to purchase and the troubles in returning flawed stock are common reasons why shoppers saw mail shopping to be more hazardous than store shopping.

\subsection{Financial Risk}

According to Grable, Lytton and O'Neill (2000) financial risk is defined as a potential net loss of money and the degree of uncertainty that a consumer is willing to accept when making a financial transaction. Besides, for Bart et al. (2005) these products are well understood and usually entail less information-searching by consumers, resulting in a lower level of perceived financial risk. In addition, website advertisers or accredited parties responsible for ensuring a website's reliability can also recommend payment protection. 
Privacy protection applies to the situation in which customers were able to control whether to disclose information to others during market transactions or consumer activities and the ability to ensure that the information provided in transactions was not disclosed to others (Chen \& Barnes, 2007). Moreover, customers are stressed that the Web still has exceptionally small security concerning utilization of credit cards and protection of individual data (Paul, 1996).

\subsection{Security and Privacy Risk}

Online shopping can be related to negative results that are not present in conventional retail, such as the failure of buyers to personally understand the quality of the product, the lack of personal communication with a seller, anxiety generation for customers who do not feel comfortable using the Internet, lack of communication and social contact with other people, and transaction protection and personal security. Perceived privacy risk is characterized as the plausibility that online businesses might use individual data improperly consequently attacking a consumer's privacy (Nyshadham, 2000). Thus, protection aspect is especially striking for online retailing. According to Tsai and Yeh (2010), the protection of knowledge and privacy of customers for online shopping is a fundamental concern for purchasing decisions. Their study also shows that customers who utilize shopping locales can gain confidence from data security and can subsequently be comfortable with buying merchandise online.

Miyazaki and Fernandez (2001) conducted research about consumer perceptions of privacy and security risks in online shopping. The most interesting is that privacy was actually a major concern for customers with longer periods of experience, indicating that the accumulation of such experience (and, potentially, information) might lead to greater concerns about privacy issues. Tasi and Yeh (2010) aimed at studying the impact of website quality, specifically product quality data, quality of service performance, website design style and features, and transaction and delivery capabilities on perceived risk of information security and privacy and its relationship to purchase intention. The results showed that there are two dimensions to the perceived risk of information security and privacy: perceived ease-of-use and perceived usefulness. Moreover, Youn (2009) specified that data security and protection are related to the instability related to how individual data is taken care of by online foundations and who has got to it.

Numerous researchers also emphasize that website security ought to encompass confidentiality of data, data astuteness, communication of non-repudiation, verification security, IT effectiveness, and security of individual protection, all of which relate to site characteristics (Shin, 2010; Kayworth \& Whitten, 2010). Lu et al. (2010) argue that online tax filing is relatively important for information security and privacy.
In addition, Shin (2010) further claimed that perceived dataimpact threatens buyers to believe in online shopping, while Rapp et al. (2009) stated that web-based privacy should be a concern between buyers and sellers, as most buyers are willing to trust local data uncovering. Safety danger in the online environment also relates to safety expectations with regard to deployment consequences and the mechanism for data storage and transmission (Kolsaker \& Payne, 2002). Aladwani (2001) found that potential clients of online keeping money appraised Web security and the protection of buyers as the foremost noteworthy future challenges confronting suppliers of e-commerce administrations.

\subsection{Purchase Intentions}

According to Pires, Stanton and Eckford (2004), whether the intended purchase was a good or a service and whether it was a high or low-involvement item was correlated with differences in perceived risk. Analysis of perceived risks for customers, disaggregated by type of risk and purchasing situation, provides insight into impediments that may impede the growth of Internet-based product buying. Previous research showed that a clear understanding of what motivates customers to shop online can influence policies, technology, and advertising decisions as well as the layout of websites (Wolfinbarger \& Gilly, 2001). Zhang et al. (2012) explored the dimensions of the perceived risk of consumers and analyzing their effect on the buying behavior of digital customers. There are five separate dimensions: perceived health risk, perceived value risk, perceived time risk, perceived delivery risk, and perceived after-sale risk. These significantly affect the purchasing behavior of online consumers. Kim et al. (2008) examined how trust and risk influence the purchasing decision of an Internet user. The study results indicate that the confidence and perceived risk of Internet customers has a strong impact on their purchasing decisions.

\subsection{Hypothesis}

Customer satisfaction can have a significant impact on the success of new customers in online shopping, both positive and negative (Tandon, Kiran \& Sah, 2017). In an online business, customer satisfaction is a key factor for productivity (Guo et al. 2012). Whereas, perceived risk was formally defined as the fear of buy-related losses and acts as a deterrent to buy action (Peter \& Ryan, 1976). The higher the risk that customers perceive, the greater the probability of not buying the product online (Tandon, Kiran, \& Sah, 2017). Forsythe and Shi (2003) reported a negative relationship between perceived risk and behavior in online shopping, and further clarified that perceived financial risk is the most reliable predictor of Internet patronage activity. 
Most of the studies found that financial risk is negatively related to online shopping intention (Khan, Liang \& Shahzad, 2015; Masoud, 2013; Al-Rawad et al., 2015). Online shopping retailers typically offer multiple payment options, such as online payment regarding credit card use; cash payment; and telegraphic remittance. The risk of payment such as fear of fraud, phishing or disclosure of private information has a negative effect on the attitude towards online shopping (Almousa, 2011; Javadi et al., 2012). Facilitating the payment process is necessary for online retailers to retain customers and improve consumer satisfaction (Lin \& Sun, 2009).

H1: The perceived product risk has a negative effect on the satisfaction of online shopping

H6: The perceived product risk has a negative effect on the purchase intention of online shopping

Blanche, Casaló and Guinalíu, (2012) examined the conditions under which the function of usability is particularly relevant. In this regard, due to the fact that perceived risk plays an important role in affecting the e-services adoption decision of users (Hsu \& Chiu, 2004), they have focused on how perceptions of risk could moderate the usability influence. Their results suggest that the impact of usability in those customers who perceive a high risk is increased, possibly because usability helps to resolve these customer concerns and generates a more favorable opinion about using a website. According to Muhammed et al. (2019), payment risk and product risk coefficient have negative signs and that means exactly what is expected as these two factors decrease the adoption of online shopping. The perceived product risk has a greater effect on the adoption of online shopping particularly for product categories where feeling and touch are important. The perceived risk of the product, such as the inability to judge the quality of the product on the Internet, was found to have a greater influence on the consumer's decision.

$\mathrm{H} 2$ : The perceived financial risk has a negative effect on the satisfaction of online shopping.

According to Cho and Lee (2006), the link between risk propensity and perceived risk has been neglected in risk-related consumer research. This finding highlights the importance of incorporating risk propensity into understanding perceived risk. Chang and Chen (2008) found that consumers' trust towards a specific online retailer significantly and negatively affects perceived risk towards the online retailer. Another major factor affecting satisfaction with online shopping is security (Guo, Ling \& Liu, 2012). Consumers have concerns regarding online website security, liability and privacy (Gefen, 2000). According to previous research (Elliot \& Fowell, 2000; Szymanski \& Hise, 2000), as security risk perception decreases, satisfaction with the online stores' information service is expected to increase. In other words, the strong security feature increases the level of satisfaction of the customer. Moreover, the positive relationship between safety and e-satisfaction is reconfirmed by Christian and France study (2005).

H3: The perceived security risk has a negative effect on the satisfaction of online shopping.

Customer satisfaction is also encouraged by security and privacy policies. Satisfaction with the information service is expected to increase as perceptions of security and privacy risk decrease (Zhou et al., 2008; Salo \& Karjaluoto, 2007). Previous studies have concluded that purchasing decisions usually involve the following types of risks: product risk, financial risks, health risk, convenience risk, quality risk, delivery risk, website design style, features and so on have a significant impact on the buying behavior of online consumers (Martin \& Camarero, 2009; Tasi \& Yeh, 2010; Almousa, 2011; Javadi et al., 2012; Zhang et al., 2012). According to San Martín \& Camarero, (2009), service quality as well as security and privacy policies have a distinct effect on satisfaction and confidence. The security and privacy policies, however, have a strong and significant impact on buyers' satisfaction perceiving high risk, whereas the effect is not important for buyers perceiving low risk.

H4: The perceived privacy risk has a negative effect on the perceived satisfaction of online shopping.

H7: The perceived privacy risk has a negative effect on purchase intention of online shopping.

Since Bauer's (1960) advocacy of risk-taking behavior as a possible measure of consumer attitude towards a purchase, perceived risk research has grown in different buying contexts. According to different views of researchers (Bhattacherjee, 2002; Cho \& Lee, 2006), faith and perceived risk are mental conditions that are cognitive or affective episodes that fluctuate with situational circumstances (Limayem \& Khalifa, 2000). Besides, Kim and Yang (2020) showed that overall, external and internal selection factors had a positive influence on repurchase intentions, and in particular, appealing to internal and external selection factors in order to promote repurchase intention. Satisfaction is not only the main driver of the desire of customers to continue shopping online (Bhattacherjee 2001), but also the secret to building and maintaining a loyal customer base (Evanschitzky et al., 2004). According to Zeithaml et al. (1996), online customers who have gotten a palatable 
administration are probably going to uncover positive social expectations, leading to increased online purchase intention. Bai et al. (2008) found that website customer satisfaction has a positive impact on buying intentions. Yen and Gwinner (2003) found that overall satisfaction with Internet self-service technologies had a positive impact on behavioral intentions, in particular on the ability of the same service provider to continue buying.

H5: The perceived satisfaction has a negative effect on purchase intention of online shopping.

\section{Research Methods and Materials}

\subsection{Research Framework}

The purpose of this study is to investigate the relationship among product risk, financial risk, security risk, privacy risk, perceived satisfaction and purchase intention through literature review and related study (see Figure 1).

\subsection{Research Survey}

Questionnaires were used in the present study. The survey for product risk focused on the first four items of the survey based on Forsythe (2006). The measurement of financial risks used five items modified from Forsythe (2006). To measure privacy and security, we included a version of the scale that consisted of the five privacy items and five security items from Chen and Barnes (2007). In order to measure perceived satisfaction, four items were modified from the scale developed by Flavián et al. (2006). Finally, to measure purchase intention, we adopt five items from Jarvenpaa et al. (2000).

\subsection{Demographic Statistics}

The printed questionnaires were distributed to 340 respondents. Among which, there were 306 responses are valid. Thus, the valid response rate of this survey is 90\%. There have been 34 invalid responses because the respondents have not answered correctly the reversed scale questions or left the answers blank (see Table 1).

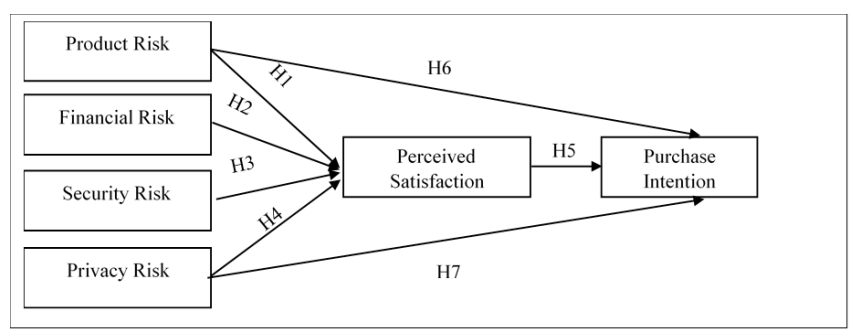

Figure 1: Research Framework

\section{Results and Discussion}

\subsection{Reliability Analysis}

In order to test the reliability of a measurement scale, item-to-total correlations (Churchill, 1979) and Cronbach's Alpha (Cronbach, 1951) are considered to be the testing elements. The scale is considered to be good enough for conducting research if it has item-to-total correlation not lower than 0.4 and Cronbach's Alpha value above 0.6 (Hair et al., 1998). Financial risk $=0.907$, product risk $=0.894$, security risk $=0.914$, privacy risk $=901$, satisfaction $=0.887$ and purchase intension $=0.836$. Comparing the current fit indices to the threshold level, the fit indices of Cronback's Alpha are very good.

\subsection{Testing Measurement Model with CFA}

Confirmatory Factory Analysis (CFA) is a good method to assess the validity and reliability of measures (Bagozzi \&

Table 1: Respondent Profile

\begin{tabular}{|c|c|c|}
\hline Category & $\begin{array}{c}\text { Number of } \\
\text { respondents }\end{array}$ & Percentage \\
\hline \multicolumn{3}{|l|}{ Gender } \\
\hline Male & 196 & $64 . \%$ \\
\hline Female & 110 & $36 \%$ \\
\hline \multicolumn{3}{|l|}{ Age } \\
\hline Less than 20 years old & 25 & $8 \%$ \\
\hline 20-30 years old & 130 & $43 \%$ \\
\hline $30-40$ years old & 75 & $25 \%$ \\
\hline $40-50$ years old & 40 & $13 \%$ \\
\hline $50-60$ years old & 30 & $10 \%$ \\
\hline Above 60 years old & 6 & $1 \%$ \\
\hline \multicolumn{3}{|l|}{ Occupation } \\
\hline Student & 123 & $40 \%$ \\
\hline $\begin{array}{l}\text { Banking/financial/ } \\
\text { insurance }\end{array}$ & 90 & $29 \%$ \\
\hline Education/ culture & 43 & $14 \%$ \\
\hline Government & 11 & $4 \%$ \\
\hline Media/publishing & 29 & $10 \%$ \\
\hline Others & 10 & $3 \%$ \\
\hline \multicolumn{3}{|l|}{ Education } \\
\hline $\begin{array}{l}\text { Senior High Diploma or } \\
\text { Below }\end{array}$ & 16 & $5 \%$ \\
\hline $\begin{array}{l}\text { Associate Bachelor } \\
\text { Degree }\end{array}$ & 86 & $28 \%$ \\
\hline Bachelor Degree & 154 & $51 \%$ \\
\hline Master Degree & 35 & $11 \%$ \\
\hline PhD Degree & 15 & $5 \%$ \\
\hline
\end{tabular}


Foxall, 1996). The goodness-of-fit of CFA is used to further assess the convergent validity among the constructs. CFA is applied with the following important indexes: Chi-square, Chi-square/df, Comparative Fit Index (CFI), Index (TLI), Root Mean Square Error Approximation (RMSEA). The goodness-of-fit for each model was assessed by examining the chi-square statistic, the comparative fit index (CFI), and the root-mean-square error of approximation (RMSEA), NFI, IFI, and CFI are greater than 0.90 ( Hair et al 1998). GFI and
AGFI index exceeds 0.8. Chi- square/df is equal or lower 2 (Chisquare/df $\leq 3$ can be accepted in some cases), and RMSEA is equal or lower 0.08 (RMSEA $\leq 0.05$ is excellent) (Hair et al, 1998). Those estimates are the precedents for the reliability of all factors for the next analyzing steps in this research.

Comparing the current fit indices to the threshold level, the fit indices of CMIN, AGFI, and RMSEA are very good. The CMIN/DF, AGFI and RMSEA satisfy the fit indices criteria perfectly. Therefore, the model fits Confirmatory

Table 2: Testing Results of Reliability and Convergent Validity of Various Conceptions

\begin{tabular}{|c|c|c|c|c|}
\hline & $\begin{array}{c}\text { Std } \\
\text { Loading }\end{array}$ & $\alpha$ & CR & AVE \\
\hline Financial Risk & & 0.907 & 0.907 & 0.66 \\
\hline 1. Can't trust the online company & 0.904 & & & \\
\hline 2. May not get the product & 0.834 & & & \\
\hline 3. May purchase something by accident & 0.792 & & & \\
\hline 4. My personal information may not be kept & 0.752 & & & \\
\hline 5. My credit card number may not be secure & 0.779 & & & \\
\hline Product Risk & & 0.894 & 0.9 & 0.69 \\
\hline 6. Can't examine the actual product & 0.854 & & & \\
\hline 7. Size may be a problem with clothes & 0.778 & & & \\
\hline 8. Can't try on clothing online & 0.804 & & & \\
\hline 9. Inability to touch and feel the item & 0.890 & & & \\
\hline \multicolumn{5}{|l|}{ Security Risk } \\
\hline 10. This website presents enough online security & 0.781 & 0.914 & 0.89 & 0.63 \\
\hline 11. Purchasing on this website will not cause financial risks & 0.769 & & & \\
\hline $\begin{array}{l}\text { 12. It is believed that online transactions on this website are protected by the latest } \\
\text { know-how }\end{array}$ & 0.736 & & & \\
\hline 13. Online payment on this website is safe & 0.804 & & & \\
\hline 14. This website has the ability to solve problems from hackers & 0.875 & & & \\
\hline Privacy Risk & & 0.901 & 0.914 & 0.682 \\
\hline 15.The personal information that I provide on this website is secure & 0.865 & & & \\
\hline 16. The monetary information that I provide on this website is well protected & 0.804 & & & \\
\hline 17. This website will not use unsuitable methods to collect my personal data & 0.778 & & & \\
\hline 18. This website does not ask for irrelevant personal information & 0.823 & & & \\
\hline 19. This website does not apply my personal information for other purposes. & 0.857 & & & \\
\hline Perceived Satisfaction & & 0.887 & 0.886 & 0.661 \\
\hline 20. I think that I made the correct decision to use this website & 0.855 & & & \\
\hline 21. The experience that I have had with this website has been satisfactory & 0.821 & & & \\
\hline 22. I am satisfied with the way that this website has carried out transactions & 0.803 & & & \\
\hline 23. I am satisfied with the service I have received from the website & 0.773 & & & \\
\hline Behavior Intentions & & 0.836 & 0.887 & 0.663 \\
\hline 24. How likely is it that you would return to this website? & 0.765 & & & \\
\hline $\begin{array}{l}\text { 25. How likely is that you would consider purchasing from this website in the next three } \\
\text { months? }\end{array}$ & 0.773 & & & \\
\hline $\begin{array}{l}\text { 26. How likely is it that you would consider purchasing from this website in the next } \\
\text { year? }\end{array}$ & 0.850 & & & \\
\hline 27. For this purchase, how likely is it that you buy from this website? & 0.867 & & & \\
\hline
\end{tabular}


Factor Analysis, so is good overall. These evidences which are $\mathrm{GFI}=0.910, \mathrm{TLI}=0.98, \mathrm{CFI}=0.98(>0.9)$, Chi-square/ df $=1.297(<2)$, RMSEA $=0.31(<0.08)$ prove the validity and reliability of measurements. Moreover, as shown in table 4.18 , the convergent validity among the constructs shows that standardized regression weights are higher than 0.5 with the significant lower than 0.05 (Gerbing \& Anderson, 1998). Therefore, no item of factors in this model needs to be deleted. In other words, all the items of factors should be kept in this research for the next step of the data analysis process (see Table 2)

\subsection{Convergent Validity}

According to Hair et al. (2010), Composite reliabilities (CR) must be larger than 0.7 , which should be more reliable. In this study, it ranged from 0.887 to 0.919 . Convergent validity was assessed in terms of factor loadings and average variance extracted. In CFA, the standardized factor loadings and the Average Variance Extracted (AVE) are utilized to test the convergent validity of constructs. The standardized factors should load above 0.5 and AVEs should exceed 0.5 (AVEs of 0.4 can be accepted) (Gerbing \& Anderson, 1988). Definitely, AVE is a strict measure of convergent validity (Malhotra \& Dash, 2011). As shown in Table 2, all items had significant factor loadings higher than 0.50 . Average variances extracted ranged from 0.63 to 0.68 , suggesting adequate convergent validity. Thus, all factors in the measurement model had adequate reliability.

\subsection{Discriminant Validity}

In order to ensure that one construct is dissimilar from others, discriminant validity should be evaluated. Both Average Variance Extracted (AVE) of two constructs should be greater than the correlation between two constructs squared (r2): AVEs > r2 (Fornell \& Larcker, 1981). The AVE was greater than the squared inter-construct correlation between any pair of constructs, which supports the discriminant validity of the constructs. The results have confirmed the discriminant validity of the five remaining constructs since all correlations satisfy the testing criteria. In other words, the five constructs have statistical evidence proving that they are distinct from each other. Thus, the measurement model demonstrated discriminate validity (see Table 3).

\subsection{Model Test}

According to Hair et al. (2010) Comparative Fit Index (CFI), Tucker \& Lewis Index (TLI), Root Mean Square Error Approximation (RMSEA) should be applied. The goodness-of-fit for each model was assessed by examining the chi-square statistic, the comparative fit index (CFI), and the root-mean-square error of approximation (RMSEA), NFI, IFI, and CFI are greater than 0.90. GFI, and RMSEA are used to assess only the overall model fit. As reliability and validity are supported, we proceed to examine the hypotheses shown in the structural model given in Figure 2 by using SEM. Analytical results are reported in Table 4. Model fit is acceptable $(\mathrm{CMIN}=543.261 ; \mathrm{df}=312 ; \mathrm{p}<0.001$; $\mathrm{x} 2 / \mathrm{df}=1.741 ; \mathrm{CFI}=0.964 ; \mathrm{RMSEA}=0.049)$. The paths in the model are all significant. Therefore, the five hypotheses are all supported (see Figure 2).

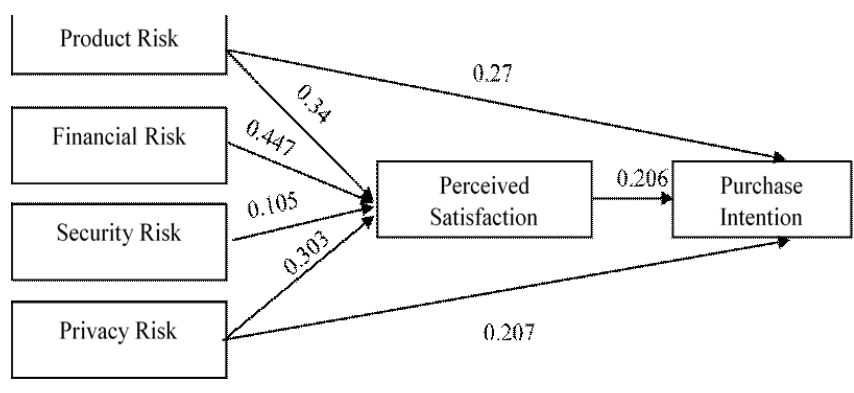

Figure 2: Model Test

Table 3: Correlations among the constructs

\begin{tabular}{|l|c|c|c|c|c|c|}
\hline & Product risk & Financial risk & Security risk & Privacy risk & $\begin{array}{c}\text { Perceived } \\
\text { Satisfaction }\end{array}$ & $\begin{array}{c}\text { Purchase } \\
\text { intention }\end{array}$ \\
\hline Product risk & 1 & & & & & \\
\hline Financial risk & .664 & 1 & & & & \\
\hline Security risk & 0.679 & 0.666 & 1 & & & \\
\hline Privacy risk & 0.599 & 0.623 & 0.547 & 1 & & \\
\hline $\begin{array}{l}\text { Perceived } \\
\text { Satisfaction }\end{array}$ & 0.645 & 0.652 & 0.651 & 0.637 & 1 & \\
\hline Purchase intention & 0.654 & 0.670 & 0.622 & 0.619 & 0.638 & 1 \\
\hline
\end{tabular}


A further evaluation in the structural model indicates that financial risk has a significant, negative influence on satisfaction (standardized coefficient $\beta=0.340$ ) and behavioral intentions $(\beta=0.27)$. Thus, $\mathrm{H} 1$ and $\mathrm{H} 6$ are supported. In addition, product risk has a significant, negative impact on customer satisfaction $(\beta=0.447)$. Thus, $\mathrm{H} 2$ and is supported. The next investigation in this study was assessing the relationship between security risk and satisfaction online shopping. The results showed there is a negative relation between these two variables $(\beta=0.105)$. Thus, $\mathrm{H} 3$ is supported. The fourth hypothesis stated that privacy risk ease-of-use has negative effect to perceived satisfaction $(\beta=0.303)$ and behavior intention $(\beta=0.207)$. Thus, $\mathrm{H} 4$ and $\mathrm{H} 7$ are supported. Finally, Customer satisfaction is also proved to have a significant, positive effect on behavioral intentions $(\beta=0.926)$. The results of the direct path show the hypotheses H1, H2, H3, H4, H5, H6, and H7 are supported (see Table 4).

\subsection{Discussions}

The study results showed that product perceived risk negatively influences the consumers' satisfaction to buy online. Specifically, they negatively correlate with and negatively affect online shopping adoption in Vietnam. The importance of identifying and reducing perceived risks is greatly attributed to the distinction between different types of risks and to use them to examine perceptions of online purchase risks. This helps to better identify the differences in perceived risk and, thus, enhance the precision with which actions to reduce risk can be taken.

Security risk is one of the effective perceived risk types for online shopping and in the literature; Financial Risk and Information Security Risks correspond to Security Risk. The content of the questions of security risk is about security shopping without any loss and being secure about personal information. With the literature review, we can see that most of the studies find financial risk an effective risk type for online shopping, and it is negatively related to online shopping (Khan, Liang, and Shahzad, 2015). Perceived risk negatively correlated with consumer satisfaction as indicated in a previous study (Doolin et al., 2005) aside from lowering consumers' purchase intentions (McKnight et al., 2002). In other words, high consumer perceived risk toward online stores reduces consumers' perceived satisfaction. The decrease in consumers' perceived risks toward online shopping increased consumers' purchase intentions (Pires et al., 2004). These findings support our study about the negative effect of perceived security risk on online shopping. Regarding purchase intention, Perceived satisfaction was the most influential factor of purchase intention. In the current competitive online shopping market, maintaining long-term satisfactory relationship with customers was the key to success. The number of Internet safety is increasing. Perceived risk has become an important factor for online shopping. Therefore, security and privacy caused a perceived risk.

\section{Conclusions}

After a literature review and analysis of our questionnaire's results, we discover four types of perceived risk: security risk, financial risk, product risk, and privacy risk. SPSS 20 is used for Factor Analysis and we use Principal Component Analysis as extraction method. After Structural Equation Modeling (SEM) on AMOS 20, it was found that security risk, financial risk, product risk and privacy risk have a significant effect on satisfaction and behavior intention for online shopping. Consumers worry to shop online because they have concerns about using their credit cards; they fear their personal information will be used elsewhere. In this study, customers in Vietnam are more concerned about using their credit cards credentials than towards quality of the product.

\subsection{Managerial Implications}

The main contribution of this study is to create a framework to assess the effect of perceived risk types on online shopping. Managers need to take perceived risk

Table 4: Result of the hypothesis test

\begin{tabular}{|l|c|}
\hline \multicolumn{1}{|c|}{ Hypothesis Test } & Hypothesis \\
\hline H1: The perceived product risk has a negative effect on the satisfaction of online shopping & Supported \\
\hline H2: The perceived financial risk has a negative effect on the percieved satisfaction of online shopping. & Supported \\
\hline H3: The perceived security risk has a negative effect on the perceived satisfaction of online shopping & Supported \\
\hline H4: The perceived privacy risk has a negative effect on the perceived satisfaction of online shopping. & Supported \\
\hline H5: The satisfaction has a negative effect on purchase intention of online shopping. & Supported \\
\hline H6: The perceived product risk has a negative effect on the purchase intention of online shopping & Supported \\
\hline H7: The perceived privacy risk has a negative effect on purchase intetion of online shopping. & Supported \\
\hline
\end{tabular}


into account when designing their electronic marketing channels. In addition, shopping websites should strengthen their transaction security by appropriately using various available resources and new information technologies. The establishment of website functions and the promotion of website security enhance consumers' online shopping experiences and desires. To reduce perceived risk, frequentlyupdated information should be provided to improve the website contents; online vendors need to understand the factors that influence the formation of consumer's satisfaction toward online shopping.

Online retailers should send notifications to all their customers assuring them of the security of their online transactions; this will help reduce the financial risk. How to enhance financial risk, product risk, security, and privacy as well as increase consumer flow experience in order to reduce the perceived risk is at the core of online shopping. Websites should strengthen the quality and quantity of product information. For the aspects of security and privacy, websites should provide consumers with reliable safety features. Finally, websites should also increase the fluency and positive experience of consumers and improve the interactive features of a website. Meanwhile, websites need to collect feedback about consumer problems and provide customized information in order to increase the chance of interaction between the consumers and the website. This study provided the online retailer with additional knowledge regarding the intensity and types of online shopping perceptions influencing its customers. Based on such knowledge, the online retailers would be able to position their marketing strategies to attract new online shoppers.

\subsection{Research Limitations}

As with any study, this one has some limitations. First, as regards the data collection method, questionnaires were distributed to respondents and it unexpectedly excludes all the respondents who cannot read or do not have enough knowledge to understand the survey questions. Perhaps, another study would be conducted in the future in order to solve these limitations. Secondly, for convenience, we use mostly student samples. Even though students are important online shoppers, other important customers, like young white-collar workers, have been ignored. Thirdly, this study measures students' overall attitudes toward four online retailers and does not focus on one specifically. The general opinion might not reflect the actual performance of each online retailer. Fourthly, this study did not collect the purchase intention of other countries' consumers. This study focused on the consumer online shopping experience in Vietnam. This study suggests that future research investigates the consumer purchase intention of other countries to learn about other purchase intentions

\section{References}

Al-Rawad, M. I., Al Khattab, A., Al-Shqairat, Z. I., Krishan, T. A., \& Jarrar, M. H. (2015). An Exploratory Investigation of Consumerse Perceptions of the Risks of Online Shopping in Jordan. International Journal of Marketing Studies, 7(1), 157167. https://doi.org/10.5539 /ijms.v7n1p157

Aladwani, A. M. (2001). Online banking: a field study of drivers, development challenges, and expectations. International Journal of Information Management, 21(3), 213-225.

Almousa, M. (2011). Perceived risk in apparel online shopping: A multi-dimensional perspective. Canadian Social Science, 7(2), 23-31.

Bagozzi, R., \& Foxall, G. (1996). Construct validation of a measure of adaptive-innovative cognitive styles in consumption. International Journal of Research in Marketing, 13, 201-213.

Bagozzi R.P., \& Yi, Y. (1988). On the evaluation of structural equation model. Journal of Academy of Marketing Science, 16 (1), 74-94.

Bauer, R.A. (1960). Consumer behavior as risk taking. In: Hancock, R.S., Ed., Dynamic Marketing for a Changing World, Proceedings of the 43rd. Conference of the American Marketing Association, 389-398.

Bhattacherjee, A. (2002). Individual trust in online firms: Scale development and initial test. Journal of Management Information Systems, 19, 211-241

Bhattacherjee, A. (2001). An empirical analysis of the antecedents of electronic commerce service continuance. Decision Support System, 32(2), 201-214.

Bai., B., Law R., \& Wen., I. (2008). The impact of website quality on customer satisfaction and purchase intentions: evidence from Chinese online visitors. International Journal of Hospitality Management 27(3), 391-402.

Bart, Y., Shankar, V., Sultan, F., \& Urban, G. (2005). Are the drivers and role of online trust the same for all Web sites and consumers? A large-scale exploratory empirical study. Journal of Marketing, 69(4), 133-152.

Belanche, D., Casaló, L. V., \& Guinalíu, M. (2012). Website usability, consumer satisfaction and the intention to use a website: The moderating effect of perceived risk. Journal of Retailing and Consumer Services, 19(1), 124-132.

Chang, H.H., \& Chen, S.W. (2008). The impact of online store environment cues on purchase intention, trust, and perceived risk as a mediator. Online Information Review, 32(6), 818-841.

Chang, S.H., Chih, W. H., Liou, D.K., \& Yang, Y.T. (2016). The mediation of cognitive attitude for online shopping. Information Technology \& People, 29(3), 618-646.

Chen, Y.H., \& Barnes, S. (2007). Initial trust and online buyer behavior. Industrial Management \& Data Systems, 107(1), 21-36.

Cho, E \& Lee, J. (2006). An integrated model of risk and riskreducing strategies. Journal of Business Research, 59(1), $112-120$ 
Churchill, G. A. J. (1979). A paradigm for developing better measures of marketing constructs. Journal of Marketing Research, 16(2), 64-73.

Childers, T.L., Christopher, L.C., Peck, J. \& Carson, S. (2001). Hedonic and utilitarian motivations for online retail shopping behavior. Journal of Retailing, 77(4), 511-535.

Doolin, B., Dillon, S., Thompson, F., \& Corner, J.L. (2005). Perceived risk, the Internet shopping experience and online purchasing behaviour: a New Zealand perspective. Journal of Global Information Management, 13(2), 66-92.

Evanschitzky, H, Iye,r G.R, Hesse, J, Ahlert. D (2004). E-satisfaction: a re-examination. Journal of Retail, 80(3), 239-247.

Engel, J.F., \& Blackwell, R. (1970). Perceived risk in Mail-Order and retail store buying. Journal of Marketing Research, 7(3), 364-369

Elliot, S., \& Fowell, S. (2000). Expectations versus reality: a snapshot of consumer experiences with Internet retailing. International Journal of Information Management, 20(5), 323-336.

Flavián, C., Guinalíu, M. \& Gurrea, R. (2006). The role played by perceived usability, satisfaction and consumer trust on website loyalty. Information and Management, 43(1), 1-14.

Forsythe, S. M., \& Shi, B. (2003). Consumer patronage and risk perceptions in Internet shopping. Journal of Business Research, 56(2004), 867-875.

Fornell, C., \& Larcker, D. F. (1981). Evaluating structural equation models with unobservable variables and measurement error. Journal of Marketing Research, 48, 39-50.

Guo, X.Y., Ling, K.C., \& Liu, M. (2012). Evaluating Factors Influencing Consumer Satisfaction towards Online Shopping in China. Asian Social Science, 8(13), 40-50.

Grable, J., Lytton, R. \& O’Neill, B. (2004). Projection bias and financial risk tolerance. The Journal of Behavioral Finance, 5(3), 142-147.

Gerbing, D.W., Anderson, J.C., 1988. An updated paradigm for scale development incorporating unidimensionality and its assessment. Journal of Marketing Research, 25(2) 186-192.

Gefen, D. (2000). E-Commerce: the role of familiarity and trust. The International Journal of Management and Science, 28, 725-737.

Giao, H. N. K. (2020). Customer satisfaction at Tiki.vn e-commerce platform. Journal of Asian Finance, Economics and Business, 7(4), 173-183. https://doi.org/10.13106/jafeb.2020.vol7.no4.173

Grace Lin, T. R., \& Chia, C. S. (2009). Factors influencing satisfaction and loyalty in online shopping: an integrated model. Online Information Review, 33(3), 458-475.

Khan, S. A., Liang, Y., \& Shahzad, S. (2015). An empirical study of Perceived factors affecting customer satisfaction to repurchase intention in online Stores in China. Journal of Service Science and Management, 8(6), 291-305.

Kim, D., Ferrin, D. \& Rao, J. (2008). A trust-based consumer decision-making model in electronic commerce: The role of trust, perceived risk, and their antecedents. Decision Support Systems, 44, 544-564.
Kim, Y.E., \& Yang, H. C. (2020). The effects of perceived satisfaction level of high-involvement product choice attribute of millennial generation on repurchase intention: Moderating effect of gender difference. Journal of Asian Finance, Economics and Business, 7(1), 131-140. https://doi.org/10.13106/jafeb.2020. vol7.no1.131

Kolsaker, A., \& Payne, C. (2002). Engendering trust in e-commerce: a study of gender-based concerns. Marketing Intelligence and Planning, 20(4), 206-214.

Ko, H., Jung, J., Kim J., \& Shim, S.W. (2004). Cross-cultural differences in perceived risk of online shopping. Journal of Interactive Advertising, 4(2), 20-29.

Kayworth, T., \& Whitten, D. (2010). Effective information security requires a balance of social and technology factors. MIS Quarterly Executive, 9(3), 163-175.

Kim, D., Ferrin, D., \& Rao, J. (2008). A trust-based consumer decision-making model in electronic commerce: The role of trust, perceived risk, and their antecedents. Decision Support Systems, 44, 544-564.

Hsu, M., Chiu, C., (2004). Predicting electronic service continuance with a decomposed theory of planned behaviour. Behaviour and information Technology, 23, 359-373.

Hair, J.F.J., Anderson, R.E., Tatham, R.L., Black, W.C., 1998. Multivariate Data Analysis, (5th ed.). Upper Saddle River, New Jersey: Prentice Hall.

Hair, J. F. et al. (2010). Multivariate data analysis (7th ed.). Upper Saddle River, NJ: Prentice-Hall.

Javadi , M., Dolatabadi, H.. Nourbakhsh , M. Poursaeedi, A., \& Asadollahi, A. (2012). An Analysis of Factors Affecting on Online Shopping Behaviour of consumers. International Journal of Marketing Studies, 4(5), 81-98.

Jarvenpaa, S., \& Noam, T. (1999). Consumer trust in an Internet store: A cross-cultural validation. Journal of ComputerMediated Communication, 5(2).45-71.

Jarvenpaa, S.L., Tractinsky, N. \& Vitale, M. (2000). Consumer trust in an Internet store. Information Technology and Management, $1(1 / 2), 45-71$.

Lee, E.J. \& Overby, J.W. (2004). Creating value for online shoppers: implications for satisfaction and loyalty. Journal of Consumer Satisfaction, Dissatisfaction and Complaining Behavior, 17(1), 54-67.

Limayem, M., Khalifa, M., \& Frini., A. (2000). What makes consumers buy from Internet? A longitudinal study of online shopping. IEEE Transactions on Systems, Man and Cybernetics Part A (Systems and Humans), 30(4), 421-432.

Lin, G. T. R., \& Sun, C. C. (2009). Factors influencing satisfaction and loyalty in online shopping: an integrated model. Online Information Review, 33(3), 458-475.

Malhotra, N.K., \& Dash, S. (2011). Marketing Research: An Applied Orientation. London: Pearson Publishing

Martin, S. \& Camarero, C. (2009). How perceived risk affects online buying. Online Information Review, 33(4), 629-654. 
Masoud, E. Y. (2013). The Effect of Perceived Risk on Online Shopping in Jordan. European Journal of Business and Management, 5(6), 76-88.

McKnight, D. H., Choudhury, V. and Kacmar, C. (2002) Developing and Validating Trust Measures for e-Commerce: An Integrative Typology. Information Systems Research, 13, 334-359.

McGaughey, R. E., \& Mason, K. H. (1998). The internet as a marketing tool. Journal of Marketing: Theory and Practice, $6(3), 1-11$.

Miyazaki, D., \& Fernandez. A (2001). Consumer Perceptions of Privacy and Security Risks for Online Shopping. The journal of consumer affairs, 35, 27-44.

Mitchell, V.W.(1999). Consumer perceived risk: conceptualisations and models. European Journal of Marketing, 33(1/2), 163-195.

Muhammed, A., Nadar, I., Zaid, N., \& Midhat, F. (2019). The perceived risks affecting online shopping adoption in Jordan. International Journal of Online Marketing, 9(2), 448-458.

Montoya-Weiss, M. M., Voss, G. B., \& Grewal, D. (2003). Determinants of Online Channel Use and Overall Satisfaction with a Relational, Multichannel Service Provider. Journal of the Academy of Marketing Science, 31(4), 448-458. https://doi. org/10.1177/0092070303254408

Nyshadham, E. A. (2000). Privacy policies of air travel web sites: a survey and analysis. Journal Air Transport Management, 6(3), 143-152

Novak, T. P., Hoffman, D. L. \& Yung, Y. F. (2000). Measuring the customer experience in online environments: A structural modelling approach. Marketing Science, 19(1), 22-42.

Peter, J.P., \& Ryan, M.J (1976). An investigation of perceived risk at the brand level. Journal Marketing Research, 2(13), 184-188.

Pires, G., Stanton, J., \& Eckford, A. (2004). Influences on the perceived risk of purchasing online. Journal of Consumer Behavior, 4, 118-131

Rosen, K.T., \& Howard, A.L. (2000). E-retail: gold rush or fook's gold? California Management Review, 42(3), 72-100.

Rapp, J., Hill, R.P, Gaines, J., \& Wilson, M.R. (2009). Advertising and consumer privacy: old practices and new challenges. Journal of Advertising, 38(4), 51-61.

Raynolds, J. (2000). Ecommerce: a critical review. International Journal of retail \& Distribution Management, 30(2), 19-30.

Paul, B (1996). Marketing on the Internet. Journal of Consumer Marketing, 14(3), 27-39.

Shin, D.H. (2010). Ubiquitous computing acceptance model: end user concern about security, privacy and risk. International Journal of Mobile Communication, 8(2), 169-186.
Skadberg, Y.X., \& Kimmel, J.R. (2004). Visitors' flow experience while browsing a web site: its measurement, contributing factors and consequences. Computers in Human Behavior, 20(3), 403-422.

Szymanski, D. M., \& Hise, R. T. (2000). E-Satisfaction: an initial examination. Journal of Retailing, 76(3), 309-322.

Spiller, P \& Lohse, G.L. (1997). A Classification of Internet Retail Stores. International journal of electronic commerce, 2(1), 29-56.

Salo, J. \& Karjaluoto, H. (2007). A conceptual model of trust in the online environment. Online Information Review, 31(5), 604-621.

Tasi, Y. \& Yeh, J. (2010). Perceived risk of information security and privacy in online shopping: A study of environmentally sustainable products. African Journal of Business Management, 4(18), 4057-4066.

Tandon, U., Kiran, R., \& Sah, A. N. (2017). The influence of website functionality, drivers and perceived risk on customer satisfaction in online shopping: an emerging economy case. Information Systems and e-Business Management, 16(1), 5791.

Tham, K. W., Dastane, O., Johari, Z., \& Ismal, N.B. (2019). Perceived risk factors affecting consumers' online shopping behaviour. Journal of Asian Finance, Economics and Business, 6(4), 246-260. https://doi.org/10.13106/jafeb.2019.vol6. no4.249

Zhang, L., Tan, W., Xu, Y., \& Tan, G. (2012). Dimensions of consumers' perceived risk and their influences on online consumers' purchasing behaviour. Communications in information science and management engineering, 2(7), 8-14.

Zhou, M., Dresner, M., \& Windle, R.J. (2008). Online reputation systems: design and strategic practices. Decision Support Systems, 44(4), 785-797.

Wolfinbarger, M. \& Gilly, M. (2001). Shopping online for freedom, control and fun. California Management Review, 43(2), 34-55.

Yen, H. J. R., \& Gwinner, K.P. (2003). Internet retail customer loyalty: the mediating role of relational benefits. International Journal of Service Industry Management, 14(5), 483-500.

Youn, S. (2009). Determinants of online privacy concern and its influence on privacy protection behaviors among young adolescents. Journal of Consummer Affairs, 43(3), 389-418.

Zeithaml, V.A, Berry, L.L., \& Parasuraman, A. (1996). The behavioral consequences of service quality. Journal of Marketing, 60(2), 31-46. 